\title{
Adenovirus Encoding Human Aquaporin-1
}

National Cancer Institute

\section{Source}

National Cancer Institute. Adenovirus Encoding Human Aquaporin-1. NCI Thesaurus.

Code C68932.

A replication-deficient, recombinant adenovirus encoding human aquaporin-1 with potential membrane water channel activity. Upon transfection of salivary glands, adenovirus encoding human aquaporin-1 (AdhAQP1) directs human aquaporin-1 (hAQP1) expression in the apical and basolateral plasma membranes of salivary secretory cells, which may result in increased saliva production. hAQP1, a water channel protein, is one of several highly conserved water channel proteins that mediate water permeability in cells of water-transporting tissues. 